Vol. 2 | No. 1 | $2021 \mid$ Hal. 85-89

\title{
LAYANAN PENDAMPINGAN BELAJAR DAN ENGLISH CLUB PADA MASA COVID- 19 UNTUK SISWA SEKOLAH DASAR
}

\author{
Ifit Novita Sari*, Erico Dwi Novienda Putra, Nadiyatus Sabila, Hamid \\ Fakultas Keguruan dan Ilmu Pendidikan, Universitas Islam Malang \\ *korespondensi email: inovsari@unisma.ac.id
}

\begin{abstract}
ABSTRAK
Pada masa pandemi seperti sekarang ini banyak sekolah yang mengharuskan peserta didiknya belajar dari rumah dengan cara daring. Seperti halnya anak-anak di Dusun Santrean, setiap harinya, peserta didik diberikan materi dan tugas baru oleh guru mereka guna menjaga proses berlangsungnya kegiatan belajar mengajar. Maka dari itu, diperlukan pendampingan belajar yang lebih intensif selain belajar di rumah secara mandiri. Tujuan dari kegiatan ini adalah untuk membantu anak-anak yang kesulitan ketika tengah mengerjakan tugas. Kegiatan tambahan berupa mengajarkan berbahasa inggris dengan tema yang sudah disesuaikan dalam kegiatan sehari-hari. Hal ini dimaksudkan untuk memberi bekal bagi anak-anak yang akan membawa manfaat bagi mereka di masa yang akan datang. Kegiatan ini sangat didukung oleh orang tua siswa, karena ada yang mendampingi putra putrinya belajar selain dengan orang tua mereka.
\end{abstract}

Kata Kunci: pendampingan belajar; english club; dusun Santrean

\section{PENDAHULUAN}

Pendidikan adalah hal yang paling penting untuk kemajuan anak. Anak yang menempuh pendidikan dengan baik akan mencerminkan pola pikir dan perilaku yang terdidik pula. Tentunya hal ini menjadi tanggung jawab kita semua untuk mewujudkan sistem pendidikan yang relevan dengan keadaan seperti sekarang. Dengan berkembangnya zaman yang terus berubah secara signifikan dari pola pikir yang awam dan kaku menjadi lebih modern (Suhartoyo et al., 2020).

Namun pada saat ini, berlangsungnya kegiatan belajar mengajar secara luring tidak diijinkan dengan adanya pandemi Covid-19 yang tengah melanda Indonesia. Pada awal tahun 2020 lalu, yang mengharuskan mayoritas kegiatan di luar rumah di batasi termasuk sekolah. Hal ini bertujuan untuk mengurangi kontak fisik antar peserta didik supaya menekan angka persebaran virus Covid-19 (WHO, 2020). Selama pandemi para pelajar harus belajar secara daring atau sering di kenal dengan istilah study from home.

Pembelajaran diselenggarakan dengan sistem dalam jaringan (daring) untuk menjangkau kelompok target yang massif dan luas, sehingga pembelajaran daring dapat di selenggarakan di mana saja serta diikuti secara gratis maupun berbayar (Bilfaqih \& Qomarudin, 2015; Dewi \& Handayani, 2020). Selain itu, pembelajaran daring memiliki manfaat seperti membangun komunikasi serta diskusi antara guru dengan peserta didik. Peserta didik saling interaksi dan berdiskusi satu dengan lainnya. Memudahkan anak berinteraksi dengan guru dan orang tua, sarana yang tepat untuk melihat langsung perkembangannya, guru dapat dengan mudah memberikan materi kepada anak berupa 
gambar, video, audio yang dapat di unduh oleh orang tua langsung dan, mempermudah guru membuat materi dimana saja dan kapan saja (Sobron et al., 2019).

Pelajar sekolah dasar (SD) di Dusun Santrean Desa Sumberejo Kota Batu ini, mayoritas orang tua mereka bekerja sebagai petani sayur. Mereka kurang mendapatkan pendampingan belajar dari orang tua ketika di rumah. Oleh karena itu mahasiswa mengadakan kegiatan KSM-T dengan program pendampingan belajar dan English Club. Kegiatan pendampingan belajar dapat membantu pelajar SD untuk mengerjakan tugas yang diberikan guru di sekolah. Sedangkan program English club merupakan kegiatan belajar bahasa Inggris dengan konteks kegiatan sehari-hari, sehingga lebih mudah untuk di pahami oleh anak anak.

\section{METODE}

Kegiatan pendampingan belajar dan English Club ini merupakan upaya untuk memaksimalkan proses pendidikan pada saat pandemi Covid-19. Seluruh kegiatan dilaksanakan di TPQ darul Ulum Dusun Santrean Desa Sumberejo Kota Batu, Jawa Timur. Kegiatan ini di mulai tanggal 3 Februari 2021 sampai dengan tanggal 24 Februari 2021. Kegiatan ini di awali dengan diskusi bersama mahasiswa KSM-T dan Kepala Desa terkait serta perizinan dari TPQ Darul Ulum tempat yang akan dituju nantinya. Metode yang digunakan pada kegiatan KSM-T yaitu service learning dengan arahan penuh dari dosen pembimbing lapangan.

Adapun tahapan learning yang dilakukan mahasiswa dalam pelaksanaan KSM-T kali ini dimulai dengan: pertama, survey lokasi. Survey lokasi ini bertujuan untuk menyesuaikan dengan tema kegiatan yang telah di pilih sebelumnya serta dapat di jadikan acuan apakah ada masalah pendidikan lain yang terjadi selama pandemi Covid-19 yang dapat di cari penyelesaiannya selama kegiatan berlangsung.

Kedua, diskusi bersama kepala desa sumberejo. Kegiatan ini diwakili oleh 2 mahasiswa KSM-T yang berdiskusi dengan Kepala Desa setempat dan meminta izin serta serta pemaparan oleh Kepala Desa tentang masalah pendidikan yang terjadi di wilayah setempat, dengan harapan mahasiswa KSM-T dapat membantu penyelesaiannya.

Ketiga, diskusi bersama pihak TPQ Darul Ulum. Setelah berdiskusi dengan pihak desa setempat, kemudian di lanjutkan dengan pihak TPQ Darul Ulum yang nantinya akan menjadi tempat pelaksanaan kegiatan ini. Dengan menjelaskan konsep acara pendampingan belajar dan English club yang akan di terapkan pada murid murid disana selain belajar mengaji.

Keempat, diskusi dengan wali murid. Pelaksanaan kegiatan pendampingan belajar dan English Club melibatkan anak anak usia sekolah dasar, oleh karena itu di perlukan sosialisasi kepada wali murid serta perizinan untuk anak anak mereka supaya dapat mengikuti kegiatan ini dengan baik. Mengingat kegiatan ini di laksanakan di tengah suasana pandemi.

Kelima, pelaksanaan kegiatan. Pada kegiatan pelaksanaan program merupakan bentuk service mahasiswa KSM-T kelompok 53 yang mulai mengajar dengan menggunakan protokol kesehatan. Langkah protokol kesehatan berupa memakai masker, mencuci tangan dan memakai hand sanitizer sebelum memasuki kelas serta mengatur jumlah siswa dalam 1 kelas, maka dari itu kegiatan dibagi menjadi 3 kelas untuk menghindari kerumunan yang masif dalam 1 tempat.

Keenam, analisis kegiatan. Analisis kegiatan perlu dilakukan guna mengetahui kekurangan pada kegiatan pendampingan belajar dan English Club yang akan berguna pada tahap selanjutnya yaitu tahap evaluasi.

Ketujuh, evaluasi hasil kegiatan. Setelah melakukan tahap analisis, kemudian di evaluasi. Tujuannya adalah untuk mengetahui apa saja kendala atau masalah yang ditemui 
sepanjang pelaksanaan kegiatan, sehingga dapat menemukan solusi bersama terhadap masalah masalah tersebut.

\section{HASIL DAN PEMBAHASAN}

Dengan situasi pandemi Covid-19 seperti saat ini yang terus berlangsung, kegiatan belajar mengajar yang dulunya dilaksanakan di sekolah kini menjadi berjarak dengan metode online/daring yaitu study from home (Harnani, 2020). Pembelajaran daring dilakukan dengan menyesuaikan kemampuan sekolah masing-masing. Beberapa sekolah ada yang menggunakan teknologi digital seperi portal dari website sekolah, Zoom Meeting, Classroom, serta ada juga yang menggunakan aplikasi instan lintas platform seperti WhatsApp dan Telegram.

Dusun Santrean, Desa Sumberejo, Kota Batu adalah target utama kami, sehingga kami dapat memberikan pendampingan belajar yang maksimal selain yang sudah siswa dapatkan di sekolah. Mereka belajar secara mandiri bersama orangtua mereka, namun banyak dari orangtua mereka bekerja di luar rumah sehingga kurang mendapatkan perhatian untuk mengadakan pendampingan belajar bagi anak-anak mereka. Dampaknya banyak anak-anak yang mempunyai waktu luang hanya diisi dengan bermain bersama teman temannya (Hasanah, 2020).

Berdasarkan fakta di atas maka mahasiswa KSM-T mengadakan program kerja untuk pendampingan belajar dan English Club untuk membantu anak-anak yang kurang mendapatkan waktu belajar dengan orang tua mereka. TPQ Darul Ulum merupakan tempat yang tepat untuk melaksanakan kegiatan ini karena memiliki fasilitas kelas dan papan tulis untuk menunjang aktifitas belajar mengajar. Harapannya akan meringankan orang tua siswa dalam mendampingi anak belajar, serta menambah pengetahuan belajar berbahasa Inggris dan mengerjakan tugas yang diberikan oleh guru di sekolah.

Selama kegiatan berlangsung siswa dibagi menjadi tiga kelompok. Kelas pertama diisi oleh anak-anak usia PAUD/TK dan materi mengajarnya pun telah disesuaikan dengan kemampuan sesuai tingkatannya. Kemudian kelas kedua diisi dengan kegiatan English Club, yang mengajarkan kepada siswa tentang penggunaan bahasa Inggris yang baik dan benar. Targetnya adalah siswa memahami konteks berbahasa Inggris yang sering digunakan sehari-hari, sehingga makin mudah dipahami. Kemudian kelas yang ketiga diisi dengan pendampingan belajar untuk siswa yang mempunyai tugas dari sekolah dan mahasiswa KSM-T siap untuk memdampingi mereka mengerjakan tugas (Sari, 2020).

Adapun kegiatan pendampingan belajar dan English Club yang dilakukan oleh KSM-T selama di TPQ Darul Ulum, yaitu: 1) Belajar Mengaji. Kegiatan pertama yang dilakukan adalah belajar mengaji, di TPQ Darul Ulum ada berbagai macam tingkatan mulai dari Iqra 16, sampai Al-Quran. Selain mengajar, mahasiswa juga menambahkan materi lain seperti menghafal surat-surat pendek, menghafal doa sehari hari, dan doa sholat.

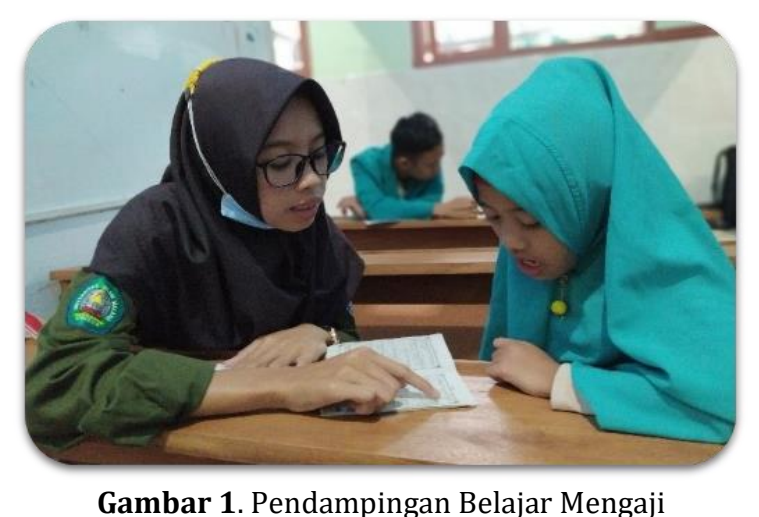


2) Belajar Mengerjakan Tugas. Selain belajar mengaji ada juga kegiatan belajar bersama dan mengerjakan tugas. Tugasnya ada berbagai macam mata pelajaran, seperti bahasa Indonesia, IPA, Matematika dll. Maka kami mencoba membantu dengan menyelesaikan tugas bersama siswa, supaya mereka juga mengetahui cara untuk mengerjakannya.

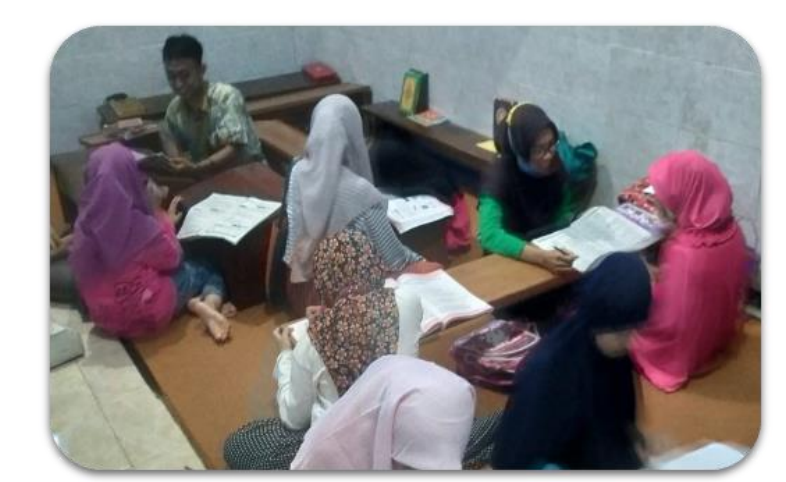

Gambar 2. Pendampingan Belajar dan Mengerjakan Tugas

3) English Club. Kegiatan English Club ini, siswa diajakan untuk menggunakan bahasa Inggris dengan baik dan benar dalam konteks kegiatan mereka sehari hari, seperti belajar memperkenalkan diri dengan menggunakan bahasa Inggris, cara untuk mengungkapkan keadaan cuaca dengan menggunakan bahasa Inggris serta membuat paragraph sederhana tentang hobi mereka.

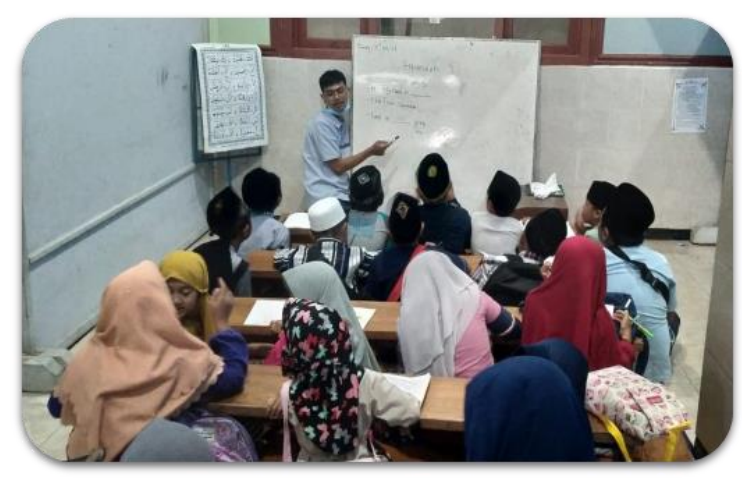

Gambar 3. English Club

\section{KESIMPULAN}

Pendampingan belajar dan English Club merupakan kegiatan yang dilaksanakan oleh mahasiswa Unisma KSM-T kelompok 53 bertempat di TPQ Darul Ulum, Dusun Santrean Desa Sumberejo Kota Batu. Kegiatan ini bertujuan untuk membantu siswa dalam memahami materi yang diajarkan di sekolah dan memberikan fasilitas bagi siswa yang kurang mendapatkan waktu belajar bersama orang tua karena bekerja di luar rumah.

Pelaksanaan kegiatan ini berupa belajar mengaji, belajar mengerjakan tugas dan English Club. Hasilnya siswa dapat belajar dengan maksimal dengan didampingi oleh mahasiswa Unisma KSM-T kelompok 53. Siswa dapat menanyakan tentang materi yang belum dipahami dan memberikan pelajaran bahasa Inggris yang sesuai dengan kebiasaan sehari-hari seperti memperkenalkan diri dalam bahasa Inggris.

Pelaksanaan kegiatan ini disambut antusias oleh siswa dan orang tua pun merasa senang dengan adanya kegiatan ini. Orang tua siswa merasa terbantu karena mayoritas dari 
mereka bekerja di luar rumah sehingga ada yang mendampingi mereka belajar dan mengerjakan tugas dari sekolah.

\section{UCAPAN TERIMA KASIH}

Ucapan terima kasih disampaikan kepada Universitas Islam Malang yang telah menyelenggarakan kegiatan KSM-T, kepala desa Sumberejo dan segenap warga dusun Santrean yang telah menerima dan memberikan ijin kepada mahasiswa untuk melaksanakan kegiatan KSM-T.

\section{DAFTAR RUJUKAN}

Bilfaqih, Y., \& Qomarudin, M. N. (2015). Esensi Penyusunan Materi Pembelajaran Daring. Deepublish.

Dewi, T. U., \& Handayani, S. L. (2020). Pelatihan Pembuatan Soal Berbasis Digital Bagi Guru SMA di Era Revolusi Industri 4.0. Jurnal Inovasi Hasil Pengabdian Masyarakat (JIPEMAS), 3(2), 146-153. https://doi.org/10.33474/jipemas.v3i2.6697

Harnani, S. (2020). EFEKTIVITAS PEMBELAJARAN DARING DI MASA PANDEMI COVID-19. Kemenag.Go.Id.

Hasanah, U. dkk. (2020). GAMBARAN PSIKOLOGIS MAHASISWA DALAM PROSES PEMBELAJARAN SELAMA PANDEMI COVID-19. Jurnal Keperawatan Jiwa. FIKKes Universitas Muhammadiyah Semarang Bekerjasama Dengan PPNI Jawa Tengah, 8(3), 299-306.

Sari, I. N. (2020). Manajemen Pembelajaran Dalam Jaringan (daring) di Masa Pandemi Covid19. In Belajar dari Covid-19: Perspektif Sosiologi, Budaya, Hukum, Kebijakan dan Pendidikan. Yayasan Kita Menulis, Medan.

Sobron, A. N., Bayu, B., Rani, R., \& Meidawati, M. (2019). Pengaruh Daring Learning terhadap Hasil Belajar IPA Siswa Sekolah Dasar. Seminar Nasional Sains \& Entrepreneurship, $1(1)$.

Suhartoyo, E., Wailissa, S. A., Jalarwati, S., Samsia, S., Wati, S., Qomariah, N., Dayanti, E., Maulani, I., Mukhlish, I., Rizki Azhari, M. H., Muhammad Isa, H., \& Maulana Amin, I. (2020). Pembelajaran Kontekstual Dalam Mewujudkan Merdeka Belajar. Jurnal Pembelajaran Pemberdayaan Masyarakat (JP2M), 1(3), 161-164. https://doi.org/10.33474/jp2m.v1i3.6588

World Health Organization (WHO). (2020). Transmisi SARS-CoV-2: implikasi terhadap kewaspadaan pencegahan infeksi (pp. 1-10). 